Investigaciones Fenomenológicas, vol. Monográfico 4/II (2013): Razón y vida, 177-190. e-ISSN: $1885-1088$

\title{
Remembering AND Forgetting AS A Fuction Of Life
}

\section{RECORDAR Y OLVIDAR COMO FUNCIÓN DE LA VIDA}

\author{
James Mensch \\ Canadian Society for Continental Philosophy/ \\ Faculty of Humanities, Charles University, Prague \\ james.mensch@gmail.com
}

\begin{abstract}
As Derrida observes, the ideal of a perfect memory has a spectral quality. The desire to achieve it is like the wish of Hanson, the fictional archaeologist, to go beyond the physical remains to grasp the past itself. What seduces us is the thought that remembering is like mechanical reproduction. We forget, however, that a photograph does not remember what we looked like any more than a recording remembers the sound of our voice. Only a living being can remember. Seen in this light, the ultimate problem of the ideal of a perfect memory is that it abstracts remembering from the context in which it functions. In this paper, I argue that this context is that of our embodied being-alive, with all the limitations that this implies. Such limitations impose a teleological structure on our remembering. They determine how memory functions on both an individual and a collective level.
\end{abstract}

Key Words: Memory, Remembering, Forgetting, Being-Alive.

\begin{abstract}
Resumen: Como observa Derrida, el ideal de la memoria perfecta tiene una cualidad espectral. El deseo de conseguirlo es como el de Hanson, el arqueólogo ficticio, de querer ir más allá de los restos físicos para alcanzar el pasado mismo. Nos seduce la idea de que recordar sea como una reproducción mecánica. Olvidamos, sin embargo, que una fotografía no recuerda cómo éramos más de lo que una grabación recuerda el sonido de nuestra voz. Sólo un ser vivo puede recordar. Desde este punto de vista, el problema último del ideal de la memoria perfecta es que abstrae el recordar del contexto en el que éste realizaría su función. En este artículo argumento que dicho contexto es el de nuestro estar-vivos encarnado, con todas las limitaciones que ello implica. Estas limitaciones imponen una estructura teleológica en nuestro recordar. Determinan como funciona la memoria, tanto a nivel individual como colectivo.
\end{abstract}

Palabras clave: Memoria, recordar, olvidar, estar-vivo.

As Derrida observes, the ideal of a perfect memory has a spectral quality. The desire to achieve it is like the wish of Hanson, the fictional archaeologist, to go beyond the remains to grasp the past itself. Seeing the Gradiva's footprint in Pompey's ashes, Hanson dreams of grasping 
the uniqueness of the printer-printed, of the impression and the imprint, of the pressure and its trace in the unique instant where they are not yet distinguished the one from the other, forming in an instant a single body of Gradiva's step, of her gait, of her pace and of the ground that carries them. (Derrida, 1996: 98-99)

The spectral quality of the ghost that haunts him is, fictionally, that of Gradiva herself. He dreams of "bringing [her] back to life", this by "reliving the singular pressure or impression that Gradiva's step [...] at that time, on that date [...] must have left in the ashes" (Derrida, 1996: 98-99). Philosophically, the spectral quality refers to a past that is no longer past, a past whose distance from the present has been erased. The ideal of such a perfect representation of the past is similar to that of a perfect map, one that would collapse the spatial distinction between the representation and the represented. In his one paragraph story, "Del rigor en la ciencia" ("On Scientific Rigor"), Borges relates how "the art of cartography attained such perfection" that "the cartographers' guilds struck a map of the Empire whose size was that of the Empire, and which coincided point for point with it". Such a map, however, proved to be "useless" and was later abandoned to the elements. Only tattered ruins remained, "inhabited by animals and beggars" (Borges, 1999: 325) ${ }^{1}$.

In both cases, what is symbolized is the misapplication of scientific rigor. Both the archaeologist and the cartographers attempt to close the gap between the representation and what it represents. Doing so, they extend their categories of exactitude and verification to areas that cannot sustain them. What seduces us to the ideal of the perfect memory is the thought that remembering is like mechanical reproduction. An old photograph of us appears to collapse the present and the past as does a recording. We forget, however, that a photograph does not remember what we looked like any more than a recording remembers the sound of our voice. Only a living being can remember. Seen in this light, the ultimate problem of the ideal of a perfect memory is that it abstracts remembering from the context in which it functions. When it does, it becomes, like the perfect map, useless for our purposes. Since only living beings remember, memory's context is that of our embodied being-alive, with all

\footnotetext{
1 This short text can be accessed at https://notes.utk.edu/bio/greenberg.nsf/0/f2d03252295e0d0585256e120009adab?OpenDocument. A jorge-lus.html
} 
the limitations that this implies. Such limitations impose a teleological structure on our remembering. They determine how memory functions on both an individual and a collective level.

\section{LIMITATIONS}

Remembering is always conjoined with forgetting. The first limitation we face is that we cannot remember everything. Some things, of course, are easy to recall, but others have sunk down and have to be searched for. From a physical point of view such forgetting presents a mystery. Is it a result of our not having enough brain cells? This hardly seems possible given that we have over 100 billion and untold connections existing between them. Phenomenologically, the answer lies in the structure of our consciousness, which always involves a foreground-background relation. Because we are embodied perceivers, we always see the world from a particular point of view. Things close to us form the foreground, those further away compose the background. Of course, we can move forward to examine the latter, but then they become part of the foreground, with the objects that were once close to us now forming the background. Given that we can view an object only from one point of view at a time, this foreground-background structure characterizes our consciousness of every object. Thus, as we walk around a chair, our present perception of it occupies the foreground, the other perceptions that we have had or anticipate having form the background. Yet, we still assert that each perception we had or will have is a perception "of" the object. This "of" designates its intentional relation to the perceived object. Phenomenologically, this signifies that we take our present perception as a member of a series of perceptions, each of which could serve as the foreground view. The intentional relation of a perception to a visible object is just such membership. As Merleau-Ponty observes, when I assume an impersonal third-person perspective and speak of the object in itself, that is, the object as it is simultaneously available to all perspectives, I dispense with this foreground-background structure ${ }^{2}$. Doing so, however, I also dispense with my perceptual awareness of the object. This is because this foreground-

\footnotetext{
${ }^{2}$ As Merleau-Ponty expresses this, "Ainsi, la position d'un seul objet au sens plein exige la composition de toutes ces expériences en un seul acte polythétique. En cela elle excède l'expérience perceptive et la synthèse d'horizons ..." (1945: 85).
} 
background structure is essential to consciousness in its intending the object. To posit an object "absolutely" without this structure is, then, to posit it in the absence of consciousness. In fact, as Merleau-Ponty writes, "the absolute positing of a single object is the death of consciousness" (1945: 85). It is its death since consciousness can perceptually relate to its objects only one view at a time. Given that our memories have the same structure as the perceptions they recall, a similar death would occur if we could remember simultaneously all the views of the object. One remembered view always forms the foreground, the rest are necessarily relegated to the background. They are not presently held in memorial consciousness. This holds not just for the memories of a specific object, but also for those of the world in which it is set. Whenever we remember, there is a focus, one that brings certain things forward and relegates others to the background.

We can understand the determination of this focus by noting a second limitation of our conscious life. This is the fact that, in regarding the external world, we are limited to the present. Outside of us, it is always now. We can neither see what is past, which has vanished, nor what is to come, which has yet to appear. Thus, at any given moment, we only intuit spatial relations ${ }^{3}$. As Kant expresses this insight, "time cannot be outwardly intuited, any more than space can be intuited as something in us" (1955: vol. 3, 52). His point is that to regard time, we must turn inward and consult our memories and anticipations. Given this, how do we verify our memories? Since the past has vanished, we cannot compare what we remember with what actually occurred through a direct, external perception. The past is available to us only through our memories, but our question concerns not their presence, but their verification. The answer is that we verify them through prediction. Suppose, for example, we remember leaving our book in an adjoining room. If we did leave it there, we can go there and find it. The memory, in other words, involves an anticipation, one that can be verified through an external perception. To see what determines the focus of our remembering, we need only ask why we want to find the book. The ready answer is that we need it for something we plan to do - say, to check a reference or to give it to a friend. The book, in other words, is necessary for our project. To take another example, we hunt in the basement for

\footnotetext{
${ }^{3}$ In this, we are like a camera, were a camera able to intuit.
} 
nails and tools, trying to remember where we put them. We do this because we need to hang a picture. As these examples indicate, the focus of our remembering is normally set by what we plan to do. Our goal determines the shape of our memories' foreground-background structure. We remember what is necessary to accomplish our project, while all the rest recedes into the background.

Fundamental to this determination is a third limitation of our being-alive. This is the fact that, as embodied, we can be in only one place at a time. As a result, we cannot do everything. We cannot, for example, set off in opposite directions down the road. We have to choose a destination. The necessity of this choice is one with the necessity of making a selection of what we want to remember, i.e., of determining the particulars of the foreground-background structure of our remembering. In other words, there is a line of determination that goes from our embodied finitude, to our having to choose between projects, to the fact that we selectively remember according to our particular goals. All of these determinations pertain to the functioning of our embodied being-alive, a functioning that is directed to a future that is grasped in terms of our goals. Traumatic memories represent a breakdown of this functioning. They constrain us to a time-loop, forcing us to relive a distressing event. They are a freezing of our memory's foreground-background structure. As such, they are a sign of the memory's inability to provide us with what we need to get on with our lives. By contrast, the random, associative arising of our memories, as happens when we daydream or are trying to fall asleep, represents the idling of this functioning.

\section{THE TEMPORALITY OF REMEMBERING}

If in normal waking life, remembering is determined by what we want to accomplish, then its functioning is essentially teleological. Projects are goal directed activities. As such, they display a unique temporality, one where the future in the form of a goal determines the past and, through this, determines the present. Thus, suppose a woman decides to become a marathon runner. Her being as an actual runner is not a present reality. Neither is it a past one. It exists as a future whose determining presence is that of a goal. How long she has to train is determined by the resources she brings to the goal -i.e., how long she has trained in the recent past. This determines her present level of 
training. As this example indicates, the goal determines the past by presenting it as a resource or material needed for the activity that will realize the intended future. In other words, the past appears as a potential that can be actualized by our present ongoing activity. Thus, the paper I purchased can appear as paper for writing, drawing, burning, etc. depending on my goal. Given that the past is "present" in memory, the same line of determination links memory to the future. I remember, for example, the paper I have purchased because I need something to write on. Similarly, my goal of becoming a marathon runner makes me call to mind how often I have trained. The determination, here, is in the form of interpretation. Not only does my intended future make me focus on some things, rather than others. It also determines how I focus on them, i.e., how I view them as means for my goal. Heidegger expresses this position in its broadest possible terms by writing that "Dasein can authentically be past only because it is directed to the future. In a certain sense, its having been springs from the future" (1967: 326) ${ }^{4}$. The sense in which the past arises from the future is in its being grasped as my potentiality to accomplish this future. Apprehended in the light of this future, it becomes my having been in the ontological sense of the potentialities that characterize my being.

The above should not be taken to imply that the past is completely passive in the sense that it has no determining role. Its status is not that of an Aristotelian pure potentiality. The line of temporal determination, in which the future determines the past, which determines the present, can be extended to the present's determining the future. So regarded, it can be considered as forming a circle:

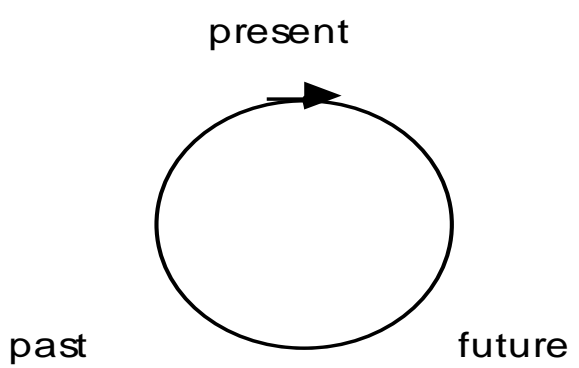

This determination of the future by the present should not be thought of in terms of physical causality. As with the determination of the past by the future,

\footnotetext{
4 "Dasein kann nur eigentlich gewesen sein, sofern es zukünftig ist. Die Gewesenheit entspringt in gewisser Weise der Zukunft". 
what is determined is interpretation. As Husserl describes this, "the style of the past becomes projected into the future" ([1917-18] 2001: 38) $)^{5}$. In other words, experiencing, we constantly anticipate. We assume that fresh experience will maintain the "style of the past". Doing so, we project the interpretations that informed our past experience. Thus, we interpret a familiar set of shapes and motions as the appearances, say, of a cat. Having often been successful at applying this schema, we use it unconsciously. Suppose, for example, we notice what seems to be a cat crouching under a bush on a bright sunny day. As we move closer to get a better look, its features seem to become more clearly defined. One part of what we see appears to be its head, another, its body, still another its tail. Based upon what we see, we anticipate that further features will be revealed as we approach: this shadow will be seen as part of the cat's ear; another will be its eye, and so forth. If our interpretations are correct, then our experiences should form a part of an emerging pattern that exhibits these features, i.e., that perceptually manifests the object we assume we are seeing. If, however, we are mistaken, at some point our experiences will fail to fulfill our expectations. What we took to be a cat will dissolve into a flickering collection of shadows. As this example indicates, to interpret is to anticipate. It is to expect, on the basis of past experience, a sequence of contents that will present the object. This expectation, even if we are not directly conscious of it, makes us attend to some contents rather than others. It serves, in other words, as a guide for our connecting our perceptions according to an anticipated pattern. As such, it determines what we see.

The schema indicated by this example is perfectly general. What makes it such is the fact that perception always involves interpretation ${ }^{6}$. We experience this whenever we regard those optical illusions in which alternative figures present themselves - for example, the one where first a girl and then an old woman appears. The switch between the two is not caused by the visual data, which remain unchanged, but by the way we take the data. The designer of the illu-

\footnotetext{
5 "[...] der Stil der Vergangenheit wird in die Zukunft projiziert".

6 As Husserl puts this point, "Zur Wahrnehmung gehört, dass etwas in ihr erscheine; aber die Interpretation macht aus, was wir Erscheinen nennen, mag sie unrichtig sein oder nicht, mag sie sich getreu und adäquat an den Rahmen des unmittelbar Gegebenen halten oder ihn, künftige Wahrnehmung gleichsam antizipierend, überschreiten. Das Haus erscheint mir - wodurch anders, als dass ich die wirklich erlebten Sinnesinhalt in gewisser Weise interpretiere. Ich höre einen Leierkasten - die empfundenen Tone deute ich eben als Leierkasten-töne. Ebenso nehme ich interpretierend meine psychischen Erscheinungen wahr, die "mich" durchschauernde Seligkeit, den Kummer im Herzen usw. Sie heißen "Erscheinungen", oder besser erscheinende Inhalte, eben als Inhalte der perzeptiver Interpretation (1992: vol. 4, 762).
} 
sion has so constructed it that it supports two separate interpretations. It allows two separate ways of synthesizing or connecting what we see, which we learned from our past experience. Interpretation is present in every sort of perception, including those that Pascal attributed to the esprit de finesse -i.e., those emotional and social perceptions that allow us to grasp our relations to others. Just as we learned to see from infancy onward by learning the patterns of perceptions that distinguished objects from their backgrounds, so we also learned how to read our own and others' emotional states. Such learning involves learning how to interpret what we experience and to anticipate accordingly. It also involves all the interpretations involved in our culture, from the interpretation of the sounds we hear as spoken language to a grasp of the meaning of our country's political symbols and gestures. Without the memory that gives us access to what we have learned, we can neither interpret nor anticipate. But this means that the future is closed off to us. We have no projects since our "having been", in the ontological sense of the potentialities that characterize our being, is no longer available. As the example of Alzheimer's disease exhibits, a complete loss of memory is a complete loss of identity.

This determination by the past is, of course, not absolute. It is matched by the past's being determined by the future. What we confront here is a double determination of interpretation -that of the past by the future and that of the future by the past. Because we project it forward, our past determines our interpretation of the future; but equally, in making us regard the past as material for our projects, the future determines how we interpret our past. The two are thus linked together in the teleological circle drawn above. As for the present, it plays the role of actualizing such determinations. Thus, the actualization of the potentialities contained in our representations of the past occurs in the present -the very same present in which we actualize the expectations that are contained in our representations of the future. The symbolism of the circle should not lead us to believe that the mutual determination of the past and the future forms a closed loop. The present that mediates between the two is not one where every expectation is fulfilled. As the example of intending to the see the cat illustrates, anticipations and, hence, interpretations are not always fulfilled. The future that we envisage, for example, that of picking up and holding the cat, can turn out to be an illusion. In its place, we find only a collection of flickering shadows. In fact, in normal perceptual life, we are constantly readjusting 
our interpretations and expectations when the data fails to support them. With this, our vision of the intended future shifts and the interpretation of the past that we base on this undergoes a corresponding change. For example, we expect a hammer to be in a certain place. We remember placing it and anticipate finding it there. But it is not there. The intended future is not made present and thus we have to readjust our memories. The same holds for perceptual experience in general. In the concrete course of our life, as we adjust our interpretations, what we see and remember have a fluid, shifting identity. As part of this life, remembering is not a mechanical recording. It is rather a living functioning. It shares life's ability to respond to its environment, both shaping it and being shaped by it. The environment makes its presence felt in the present -i.e., in its fulfilling or failing to fulfill our expectations. Responding to it, we adjust our interpretations and hence our view both of the future and the corresponding potentialities that our past affords us. We do this as we continue to work on our environment, shaping it according to a projected future. The teleological temporality that informs this shaping and being shaped is the temporality of life itself ${ }^{7}$.

\section{Collective Remembering}

Aristotle writes in his Politics that a single individual "may be compared to an isolated piece at draughts" (1253a 5). Apart from the board and the other pieces, a single piece has no sense. Similarly, one cannot speak of the concrete life of individuals without bringing in the fact of their living together. The necessity to do so comes from the fourth limitation of our being-alive. As embodied, we draw our substance from the world. In common with all other organic beings, we live from it. Our limitation, as social animals, is that such living from is collective. As a result, we never exist alone. Not only do we require an extended period of care until we reach maturity, even as adults we require others. As Aristotle expresses this, "in the first place, there must be a unity of those who cannot exist without each other; namely, of male and female" (Ibid. 1252a 27). Beyond this, there is the resulting family of children, cousins, uncles, etc. But

\footnotetext{
7 On this point, see Hans Jonas, 1996: 88-96. For an interpretation of Jonas' account of the teleological temporality of living beings, see James Mensch, 2010: 252-254.
} 
this is not sufficient to meet our needs. Different families must come together to form a village. Such villages, however, also have needs that they cannot fully meet, a fact that leads them to coalesce into a larger community, a state, to achieve self-sufficiency. As Aristotle expresses this,

When several villages are united in a single complete community, large enough to be nearly or quite self-sufficing, the state comes into existence, originating in the bare needs of life and continuing in existence for the sake of a good life. (Ibid. 1252b 27-29)

Thus, given that the "the individual, when isolated, is not self-sufficing", nor is the family, it follows that "the state is by nature clearly prior to the family and to the individual" (Ibid., 1253a 27). The priority, here, is that of functioning. Because our individual functioning presupposes the collective, we can speak of an analogous functioning on the collective level.

This point holds for the teleological temporality of this functioning. We find a parallel temporality with the same set of determinations in our collective life. Thus, the projects through which a society meets the common needs of its members express its apprehension of its future. This apprehension determines what it needs to remember to prepare for this future ${ }^{8}$. Similarly, there is a determination of the future by the past, which the society projects forward to anticipate what is coming. This means that when it cuts itself off from its past, it has no basis for anticipating the future. It is continually astonished by the events that break upon it. It does not know what to make of them since it lacks the appropriate interpretative categories. Lacking an acquaintance with its past, a society cannot grasp the resources within it required for its projects. The result is that its relation to these projects lacks reality. It becomes a form of collective daydreaming, where futures are imagined without a real sense of what it would take to achieve them or the consequence that would follow were they

\footnotetext{
${ }^{8}$ Pierre Nora sees the present age as marked by the breakdown of this structure. In his view, "it was the way in which a society, nation, group or family envisaged its future that traditionally determined what it needed to remember of the past to prepare that future; and this in turn gave meaning to the present, which was merely a link between the two". Currently, however, we are experiencing the "acceleration of history," which "essentially means that the most continuous or permanent feature of the modern world is no longer continuity or permanence but change". As a result, we can no longer envisage the future. Thus, "[w]e do not know what our descendants will need to know about ourselves in order to understand their own lives". The result is "the end of any kind of teleology of history-the end of a history whose end is known". (2002). Nora's position, in our view, is too extreme. Taken literally, it would make collective action impossible.
} 
realized. In the concrete temporality of society, we thus have a mutual determination. Without the future, in the form of collective projects, there is no focus to remembering. Without the past, we have no categories for grasping the future. As on the individual level, the past we collectively remember though our myths, stories, histories and monuments, determines our interpretation of the future, which, itself, determines the focus of this remembering.

The medium for this determination is once again the present. It either fulfills our collective expectations or disappoints them. According to the evidence it affords us, the interpretations that these expectations embody are proved to be well-founded or shown to be lacking. In a healthy society, they are revised in the light of this evidence. The future that we expect is corrected, and we reexamine what the past actually offers us. There is, in other words, a constant adjustment of anticipation and remembering. The experience of the civil rights movement in the United States, for example, led not just to a revision of the project of American equality, but also to a reinterpretation of the past. In this, different things came to prominence. The South's secession that brought on the Civil War was viewed in terms of its desire to maintain slavery rather than its insistence on "states' rights" as had been previously maintained. Similarly, historians recalled that George Washington's slaves, prompted by the chance for liberation, fought on the side of the British during the Revolutionary War. The thrust for liberation, which their actions revealed, became one of the resources required for the future envisaged by the civil rights movement.

Not all societies are equally capable of making such adjustments. A traumatic event, such as the battle of Kosovo for the Serbs, can lead to a fixation on the past and a consequent misreading of the future, one that ignores the evidence of the present ${ }^{9}$. At the opposite extreme, the reticence of the press to report on certain issues can leave a gap in the collective memory, one that can turn to astonishment when events suddenly force these issues into the open ${ }^{10}$. There are also the disturbances in our collective temporalization that result from the actions of tyrannical regimes. Under Stalin, the Soviet Union regularly

\footnotetext{
${ }^{9}$ Slobodan Milošević's Gazimestan speech, given on June 28, 1989, where he focused on the Battle of Kosovo in projecting the future of his country is an example of this. His assertion, "Six centuries later, now, we are being again engaged in battles and are facing battles," proved unhappily prophetic. The speech in Serbian and English can be accessed at http://en.wikisource.org/wiki/Gazimestan speech.

${ }_{10}$ Thus, the "astonishment" professed over the arrest of Dominique Strauss-Kahn was matched by the press's reticence to report on his sexual affairs.
} 
rewrote its history, purging its archives of all reference to fallen public figures. The official state histories, public monuments, and state-sponsored commemorations are, in a tyranny, correlated to an officially sanctioned future. They present the past as a means for achieving a set of state-approved projects. Here, the future as portrayed by the regime, takes the determining role. The past assumes a position of pure passivity. The regime, by controlling the press, controls also the evidence that would normally serve to verify the progress towards the state-approved future. The result is a closed loop, one where the remembered past and the expected future are frozen in a static relationship. As a result, the regime becomes increasingly alienated from the actually experienced world. Lacking the flexibility of a living temporality, such tyrannies do not evolve but rather persist till they suddenly break apart.

\section{Memory Versus History}

Regimes display this rigidity when they centralize power and use it to determine a unique future. When, however, power is divided, as in a democracy where different political parties through their programs represent different conceptions of the future, both the anticipated future and the remembered past are matters of public debate. As the claims of the contending parties are called into question, this debate opens up a space for the evidence of the present. In the last thirty years, not just political parties but various interest groups feminists, ethnic minorities, environmental activists, etc. - have joined this public debate. Doing so, they have laid claim not just to their versions of our collective future but also the remembered past that would offer resources to support it. The result has been a sort of democratization of remembering as various suppressed groups have laid claim to their own histories.

Some have questioned this, seeing it as a radical transformation of the notion of history. The French Academician, Pierre Nora, for example, sharply distinguishes remembering and history. He writes:

Memory is life, borne by living societies founded in its name. It remains in permanent evolution, open to the dialectic of remembering and forgetting, unconscious of its successive deformations, vulnerable to manipulation and appropriation, susceptible to being long dormant and periodically revived. History, on the other hand, is 
the reconstruction, always problematic and incomplete, of what is no longer. (1989: 9)

It is "a representation of the past". It "belongs to everyone and to no one, whence its claim to universal authority". By contrast, "there are as many memories as there are groups". In other words, "memory is by nature multiple and yet specific; collective, plural, and yet individual" (Ibid.). Given this, the conflation of the two undermines history understood "as a discipline that aspired to scientific status" (2002).

Is such a scientific status theoretically possible? At issue, here, is not the responsible treatment of historical sources, which all historians share. It is the status of our past. Can it be made a scientific object? In particular, can we abstract it from our collective life with its shifting projects and shifting focuses of remembering? As part of the living temporalization of a society, the past is necessarily involved in the debates concerning the future. Competing projects bring with them, inevitably, competing accounts of the past and, hence, competing interpretations of the potentialities it offers us. Yet, as we have seen, to isolate the past from this is to abstract it from our human reality. It is to embrace the ideal of the past that can, like Gradiva's step, be made fully present. It is, in fact, to transfer the past to the world of external perception, the world where it is always now. This is the world of inanimate objects, of objects that do not remember, that, consequently, are always in the present. The difficulty with this transfer is that the objects of history are not inanimate. They are ourselves in our temporal identity. As such, we cannot separate them from ourselves without transforming their basic sense. The basic fact here is that remembering is a function of life. It is, in its very transformations, vital to its ongoing self-affirmation. To accept these transformations, while responsibly handling the sources of the past, is to carry on the debate of public life in a way that allows such life to affirm itself. Ultimately, it signifies accepting our life in its embodied finitude with all the limitations and advantages it affords us. 


\section{ACKNOWLEDGMENT}

The research for this article was supported by the research project, "Philosophical Investigations of Body Experiences: Transdisciplinary Perspectives," Czech Science Foundation (GACR), GAP 401/10/1164, and was also supported by the The Ministry of Education, Youth and Sports - Institutional Support for Longterm Development of Research Organizations Charles University, Faculty of Humanities, PRVOUK P 18 (Charles Univ, Fac Human 2013).

\section{BIBLIOGRAPHY}

Aristotle (1941): Politics, in The Basic Works of Aristotle, trans. Benjamin Jowett, ed. Richard McKeon, New York, Random House.

Borges, Jorge Luis (1999): Collected Fictions, trans. Andrew Hurley, New York, Penguin.

Derrida, Jaques (1996): Archive Fever: A Freudian Impression, trans. Eric Preno Witz, Chicago, Chicago University Press.

Heidegger, Martin (1967): Sein und Zeit, Tübingen, Max Niermeyer Verlag.

Husserl, Edmund (1992): Logische Untersuchungen, in Edmund Husserl, Gesammelte Schriften, ed. Ursula Panzer, Hamburg, Felix Meiner Verlag.

Jonas, Hans (1996): Mortality and Morality. A Search for the Good after Auschwitz, ed. Laurence Vogel, Evanston, Northwestern University Press.

Kant, Immanuel (1955): Kritik der reinen Vernunft (2. Aufl.), in Kants gesammelte Schriften, Königliche Preussische Akademie der Wissenschaften, Berlin, Georg Reiner.

Mensch, James (2010): Husserl's Account of our Consciousness of Time, Milwakee, Marquette University Press.

Merleau-Ponty, Maurice (1945): Phénoménologie de la perception, Paris, Librairie Gallimard.

Nora, Pierre (2002): The Reasons for the Current Upsurge in Memory, Transit - Europäische Revue, Tr@nsit online, Nr. 22/2002 (http://archiv.iwm.at/index.php?option=com_content\&task=view\&id $=285 \& I t e m i d=46$ 3).

- "Between Memory and History: Les Lieux de Mémoir," Representations, No. 26, Special Issue: Memory and Counter-Memory (Spring, 1989). 